\title{
Growth performance of hybrid striped bass (Morone chrysops $\times$ M. saxatilis) fed with commercial pike perch and trout diets
}

\author{
Stephan S. W. Ende • Vanessa Fuchs • Annabel Schuhn • \\ Christiane von der Marwitz $\cdot$ Andrea Wirtz $\cdot$ Joachim Henjes • \\ Matthew Slater
}

Received: 15 May 2017/Accepted: 24 January 2018/Published online: 8 February 2018

(C) The Author(s) 2018. This article is an open access publication

\begin{abstract}
Two commercial trout diets (Oncorhynchus mykiss) and one commercial pike perch diet (Sander lucioperca) were fed to hybrid striped bass (Morone chrysops $\times$ M. saxatilis) (mean initial weight $\pm \mathrm{SD}$ of $60.7 \mathrm{~g} \pm 12.1$; mean initial length SD of $17.2 \mathrm{~cm} \pm 1.1$ ) for 69 days at rations of approximately $1 \%$ average body weight. While final body weight (FBW), final length (FBL) and condition factor (Cf) were not significantly influenced by diets, specific growth rate (SGR) in hybrid striped bass fed with the pike perch diet (1.15) was significantly higher than those fed with either of the two trout diets (1.04 and 1.07). The feed conversion ratio (FCR) in hybrid striped bass fed with the pike perch diet (1.0) was significantly lower than the FCR in hybrid striped bass fed with either of the two trout diets (1.1 and 1.2). When hybrid striped bass (mean initial body weight: $65.7 \pm 4.5$ and $127.7 \pm 2.9 \mathrm{~g}$ ) were fed with the pike perch diet twice per day until satiation for 52 days, the SGR was 1.7 and $1.15 \% \mathrm{~d}^{-1}$ in fishes with an average body weight of 116 and $183 \mathrm{~g}$, respectively. Present results demonstrate that growth performance in hybrid striped bass can be improved when fishes are fed with commercial pike perch diets rather than using commercial trout diets as is the current practice.
\end{abstract}

Keywords Hybrid striped bass · Commercial diets · Trout $\cdot$ Pike perch · Growth · Nutrition

\section{Introduction}

The hybrid striped bass (Morone chrysops $\times$ M. saxatilis) is considered an ideal candidate for aquaculture because of its fast growth, temperature tolerance, flexibility to environmental parameters, disease resistance (Kohler 2004; Morris et al. 1999). Moreover, hybrid striped bass can be produced in basically all production systems such as ponds, tanks (closed or semi-closed recirculating aquaculture systems) or cage systems (FAO 2016; Lougheed and Nelson 2001). The United States is the most significant producer of hybrid striped bass with annual production of around 6000 tons (D'Abramo and Frinsko 2008) though also other countries in Europe and Asia have recently started the production of hybrid striped bass.

Despite their commercial importance, no tailored commercial diets are available for hybrid striped bass. Basic macronutrient requirements of hybrid striped bass have been determined. Reported requirements for protein range from 40 to 41\% (Brown et al. 1992; Jaramillo and Gatlin 2004; Liu and Liao 1999; Nematipour et al. 1992; Webster et al. 1995). Energy-protein ratio requirements are between 8 and $9 \mathrm{kcal} / \mathrm{g}$

S. S. W. Ende $(\varangle) \cdot$ V. Fuchs · A. Schuhn - C. von der Marwitz · A. Wirtz · J. Henjes · M. Slater

Alfred Wegener Institute, Helmholtz Centre for Polar and Marine Research, Am Handelshafen 12, 27570 Bremerhaven,

Germany

e-mail: sende@awi.de 
(Keembiyehetty and Wilson 1998; Nematipour et al. 1992). Maximum growth with intermediate lipid deposition levels was obtained with dietary lipid levels between 10 and 15\% (Gaylord and Gatlin 2000). Though several of the essential amino acids, essential fatty acids, and vitamin and mineral requirements have been determined (Brown et al. 1993; Deng and Wilson 2003; Gaylord and Gatlin 2000; Gaylord et al. 2005; Griffin et al. 1994; Keembiyehetty and Gatlin 1997; Kocabas and Gatlin 1999; Sealey and Gatlin 1999), a complete profile of all amino acid and fatty acid requirements is missing. This knowledge gap is the main reason why commercial feeds formulated for other species are currently used in practice. Diets tailored to salmon were reportedly best suited for hybrid striped bass (Tucker Jr 2012). Growth, feed conversion and physiological indices were near optimum in hybrid striped bass weighing between 38 and $130 \mathrm{~g}$ and fed with a commercial salmon feed (45\% protein, $12 \%$ lipid) at daily rations of 1.0-1.5\% (Hung et al. 1993). However, commercial salmon diets generally contain lipid levels in excess of $12 \%$ and excess dietary lipid levels (15\%) impaired health and product quality in hybrid striped bass (Gaylord and Gatlin 2000). Catfish diets have also been tested but were not suitable for hybrid striped bass (Tucker Jr 2012). Information on performance of hybrid striped bass fed with trout diets is scarce. However, striped bass (Morone saxatilis) fed with commercial trout feed was smaller, contained less body lipid and had necrotic liver tissue compared to those fed with a salmon diet (Lemm et al. 1993). These diet-related histological changes in the livers were related to inadequate type and level of dietary essential fatty acids (Lemm et al. 1993). However, this previous observation stating that trout diets are nutritionally inadequate for hybrid striped bass dates back almost 25 years, when nutritional knowledge even for highly commercial aquaculture species like trout was largely incomplete. To our knowledge, the suitability of 'modern' trout diets and alternative 'modern' diets in general for the culture of hybrid striped bass has not been investigated yet. The aim of this study was to evaluate the suitability of a diet formulated for pike perch to culture hybrid striped bass. Suitability was evaluated on the basis of digestibility, feed conversion ratio, condition factor and maximum growth rate.

\section{Materials and methods}

Two commercial trout diets were used as reference diets. Experiments were conducted at the Centre for Aquaculture Research (ZAF, Alfred Wegener Institute Bremerhaven, Germany).

Three commercially available diets were compared in the present study: Metabolica, $3 \mathrm{~mm}$ (52\% Protein, Aller Aqua $\mathrm{GmbH}$ ) subsequently referred to as 'pike perch' diet; Supreme 15, $3 \mathrm{~mm}$ (46\% Protein, Coppens International BV) subsequently referred to as 'trout 1' diet; Efico Alpha 715, $3 \mathrm{~mm}$ (44\% Protein, Biomar Group) subsequently referred to as 'trout 2' diet. All diets were coated with sunflower oil $\left(100 \mathrm{~g} \mathrm{~kg}^{-1}\right)$ and Yttrium oxide $\left(\mathrm{Y}_{2} \mathrm{O}, 0.1 \%\right)$ as an external marker for subsequent determination of proximate composition and apparent digestibility (Hillestad et al. 1999).

\section{Fish and rearing conditions}

Hybrid striped bass $(n=180)$ were obtained from a commercial local fish farm (Fischzucht Hagedorn, Bargstedt-Ohrensen) and were transferred to the ZAF research facility where fishes were acclimatized to the rearing conditions prior to the start of the feeding experiments. The rearing/experimental system consisted of 9 rectangular glass tanks $\left(0.4 \mathrm{~m}^{-2}\right.$ bottom area and a total water volume $250 \mathrm{~L}$ per tank). All tanks were connected to a recirculation aquaculture system equipped with a mechanical filter (foam matt), a moving bed filter and a UV unit. Conditions were maintained as follows: (photoperiod 12L:12D; dissolved oxygen > 84\%; temperature $21.6 \pm 0.7^{\circ} \mathrm{C}$; total ammonia nitrogen $<0.14 \mathrm{mg} \mathrm{L}^{-1}$; nitrite nitrogen $<0.31 \mathrm{mg} \mathrm{L}^{-1}$ and nitrate nitrogen $<201.78 \mathrm{mg} \mathrm{L}^{-1}$ ). The $\mathrm{pH}$ was kept above 6.18 except for one day where the $\mathrm{pH}$ was at 5.57. The $\mathrm{pH}$ was controlled by periodically adding sodium bicarbonate to the system.

\section{Growth experiments}

Two controlled feeding (growth) experiments were conducted: 
In experiment 1 -restricted rations, three commercial diets formulated to meet the nutritional requirements of trout (two diets) and pike perch were fed at restricted rations of approximately $1 \%$ average body weight $(\mathrm{ABW})$. Hybrid striped bass were weighed and length was measured individually to the nearest of $0.1 \mathrm{~g}$ and $0.1 \mathrm{~cm}$. Fishes (mean initial weight $\pm \mathrm{SD}$ of $60.7 \mathrm{~g} \pm 12.1$; mean initial length SD of $17.2 \mathrm{~cm} \pm 1.1$ ) were randomly assigned to nine experimental tanks at a density of 20 fishes per tank. The nine tanks were randomly assigned to one of the three dietary treatments (three tanks per diet). Fishes were fed twice per day at 09:00 and 16:00 h. Feed was completely consumed, so no uneaten feed needed to be recovered for actual intake utilization calculations. At the end of the experimental period after 69 days, fishes were removed from the tanks and individually weighed and length measured.

In experiment 2-satiation, only the pike perch diet was fed twice per day to apparent satiation. Upon arrival hybrid striped bass were weighed individually to the nearest $0.1 \mathrm{~g}$. In total sixty, 30 smaller fishes (mean initial weight SD of $65.7 \mathrm{~g} \pm 4.5$ ) and 30 larger fishes (mean initial weight SD of $127.7 \mathrm{~g} \pm 2.9$ ) were selected and randomly assigned (only separated by weight) to six experimental tanks at a density of 10 fishes per tank. During the acclimatization period of 4 days, all fishes were fed with the artificial feed at a level of $0.3 \%$ average body weight. During the experimental feeding period, fishes were fed twice per day to apparent satiation (at 09:00 and 16:00 h). Previous observations showed no increase in daily feed intake when feed was provided at three meals per day or two meals per day (pers. obs.). Uneaten feed was not recovered from the tanks to avoid stress to the fish (pers. obs.). At the end of the experimental period after 52 days, fishes were removed from the tanks and weighed individually.

\section{Proximate composition and digestibility of the diets}

Prior to the digestibility trial, hybrid striped bass (originating from the previous satiation experiment) were weighed individually to the nearest $0.1 \mathrm{~g}$. In total, 48 fishes (mean weight of $312.5 \mathrm{~g}$ ) were randomly assigned to six experimental tanks at a density of 8 fishes per tank. During the acclimatization period of 5 days, fishes were fed the randomly assigned diet for their treatment tank (without the external marker) at a level of $1.5 \%$ average body weight ABW. During the experimental feeding period, fishes were fed twice per day to apparent satiation (at 09:00 and 16:00 h). Feces were siphoned out twice per day, dried and subsequently stored for further analysis. At the end of the experimental period after 28 days, fishes were removed from the tanks and weighed individually.

\section{Analytical methods and calculations}

Feed and fecal samples were dried, pooled on tank basis (applied for feces only) and homogenized by grinding before subsequent analyses of dry matter, nitrogen, energy, lipid and yttrium oxide. Samples were analyzed for dry matter according to 'Bundesamt für Verbraucherschutz und Lebensmittelsicherheit'(2004c-07b), crude protein (total nitrogen * 6.25) was determined by the Kjeldahl method according to 'Bundesamt für Verbraucherschutz und Lebensmittelsicherheit '(2004-07a), ash (gravimetrically $520{ }^{\circ} \mathrm{C}$ incineration) according to 'Bundesamt für Verbraucherschutz und Lebensmittelsicherheit'(2004-074) and crude fat (gravimetrically after extraction with petroleum ether) according to 'Bundesamt für Verbraucherschutz und Lebensmittelsicherheit'(1980-09). Proximate analysis was done at the laboratory facilities of the University of Applied Sciences (Bremerhaven, Germany). The dietary carbohydrate content (i.e., nitrogen-free extract, NFE) was calculated subtracting the sum of crude protein, crude fat and ash from 1000 in $\mathrm{g} \mathrm{kg}^{-1} \mathrm{DM}$. Gross energy (GE) was determined using an automated oxygen bomb calorimeter (Parr 6100 calorimeter, Parr Instrument GmbH, Germany) at the facilities of the AWI The digestion indicator was determined using the acid-insoluble ash (AIA) method according to, Bundesamt für Verbraucherschutz und Lebensmittelsicherheit' (2004-07).

Mean initial body weight (IBW) and mean final body weight (FBW) were calculated per tank biomass. The specific growth rate (SGR in $\%)$ was calculated as $((\ln (\mathrm{FBW})-\ln (\mathrm{IBW})) / t$, where $t$ is the experimental period (days) of the growth study. Daily feed intake (DFI; g DM fish ${ }^{-1} \mathrm{~d}^{-1}$ ) was calculated as TFI/ $(t * n)$, where TFI is the total FI per tank over the experimental days and $n$ is the number of fishes per tank. No mortalities occurred during the experiment; hence, calculations were based on eight fishes per tank. Feed 
conversion ratio (FCR) was calculated as $\mathrm{DFI} /(\mathrm{FBW}-\mathrm{IBW})$ being expressed on DM basis. Apparent digestibility of the dietary nutrients and energy (ADC) was calculated as $100 \times(1-$ dietary Y2O level/ faecal Y2O Level $\times$ faecal nutrient or energy level /dietary nutrient/energy level) (Maynard et al. 1979). The condition factor $\left(C_{\mathrm{f}}\right)$ was calculated $\mathrm{FBW} /\left(\mathrm{FBL}^{3}\right)$, where $\mathrm{FBL}$ is the final body length of the fish.

\section{Statistical analysis}

Data were log transformed to fulfill the ANOVA requirements of homoscedastic normal distribution of residuals. The effect of diet on performance parameters was analyzed by one-way ANOVA. In case of a significant effect of diet, a $t$ test was used for pairwise comparisons. Statistical significance was tested at a 0.05 probability level. All data were analyzed using the statistical software R version 3.3.1. (released 2016-06-21).

\section{Results}

The Pike perch diet exhibited markedly higher crude protein and lower nitrogen-free extract than the Trout diets (Table 1). The cumulative feed (restricted rations experiment) given to each tank over the experimental period was $753 \mathrm{~g}$.

Final body weight, final length and condition factor were not significantly affected by diets (Table 2, experiment $1 ; P=0.245, P=0.141$ and $P=0.869$ for final body weight, final length and condition factor, respectively). The FCR was significantly influenced by diet $(P=0.010)$ with FCR in hybrid striped bass fed the pike perch diet significantly lower than in those fed the trout diets. The SGR was significantly affected by $\operatorname{diet}(P=0.015)$. The SGR in hybrid striped bass fed with the pike perch diet was significantly higher than the SGR in hybrid striped bass fed with the trout diets.

\section{Discussion}

The present study showed that commercially important hybrid striped bass fed with a commercially available diet formulated for pike perch grew faster (SGR) and showed better FCR values than hybrid striped bass fed with either of two trout diets (experiment 1, Table 2). Previous observations stating that trout diets are nutritionally inadequate for hybrid striped bass date back to 1993 (Lemm et al. 1993), in which nutritional knowledge even for highly commercial aquaculture species like trout was largely incomplete. It may have been expected that hybrid striped bass perform well on advanced 'modern' trout diets.

Table 1 The proximate composition and apparent digestibility coefficients (ADC in \%) of commercial pike perch and trout diets after coating with sunflower oil $\left(100 \mathrm{~g} . \mathrm{kg}^{-1}\right)$ and Yttrium oxide $(0.1 \%)$

\begin{tabular}{lccr}
\hline & Pike perch & Trout 1 & Trout 2 \\
\hline Analysis $\left({\left.\mathrm{g} . \mathrm{kg}^{-1}\right)}^{-1} \mathrm{WW}\right)$ & & & 928.51 \\
Dry matter $\left(\mathrm{g} \mathrm{kg}^{-1}\right.$ & 918.63 & 478.89 \\
Crude protein $\left(\mathrm{g} \mathrm{kg}^{-1} \mathrm{DM}\right)$ & 538.83 & 455.82 & 168.66 \\
Crude lipid $\left(\mathrm{g} \mathrm{kg}^{-1} \mathrm{DM}\right)$ & 180.87 & 191.71 & 59.62 \\
Ash $\left(\mathrm{g} \mathrm{kg}^{-1} \mathrm{DM}\right)$ & 65.13 & 53.43 & 292.83 \\
NFE $\left(\mathrm{g} \mathrm{kg}^{-1} \mathrm{DM}\right)^{\mathrm{a}}$ & 215.17 & 299.04 & 21.7 \\
Gross energy $(\mathrm{kJ} \mathrm{g}$ & 22.27 & \\
Apparent digestibility $(\%)$ & 23.45 & & 68.22 \\
Dry matter & & 69.87 & 73.16 \\
Protein & 72.06 & 76.58 & 89.79 \\
Lipid & 74.19 & 87.59 & 73.97 \\
Energy & 88.47 & 76.66 & \\
\hline
\end{tabular}

${ }^{\mathrm{a}} \mathrm{NFE}$ (nitrogen-free extract) calculated subtracting the sum of crude protein, crude lipid and ash from 1000 in $\mathrm{g} \mathrm{kg}^{-1} \mathrm{DM}$ 
Table 2 Growth performance in hybrid striped bass (initial body weight: $60.7 \pm 12.1 \mathrm{~g}$ fed with restricted rations of pike perch and trout diets (two diets) over a period of 69 days (experiment 1), and growth performance in hybrid striped bass (initial body weight: $65.7 \pm 4.5 \mathrm{~g} \mathrm{(a)}$ and $127.7 \pm 2.9 \mathrm{~g}$ (b)) fed with the pike perch diet twice per day until satiation over a period of 52 days (experiment 2)

\begin{tabular}{|c|c|c|c|c|c|c|c|c|c|c|}
\hline \multirow[t]{2}{*}{ Diet } & \multicolumn{6}{|c|}{ Experiment 1 -restricted ration } & \multicolumn{4}{|c|}{ Experiment $2-$ satiation } \\
\hline & Pike Perch & SD & Trout 1 & SD & Trout 2 & SD & Pike Perch ${ }^{\mathrm{a}}$ & SD & Pike Perch ${ }^{\mathrm{b}}$ & $\mathrm{SD}$ \\
\hline Final body weight (g) & 134.2 & 3.67 & 124.7 & 2.32 & 127.2 & 1.91 & 167.78 & 5.85 & 239.77 & 3.46 \\
\hline Final total length $(\mathrm{cm})$ & 20.7 & 0.08 & 19.8 & 0.15 & 20 & 0.52 & - & - & - & - \\
\hline Specific growth rate $(\%)$ & $1.15^{\mathrm{a}}$ & 0.04 & $1.04^{\mathrm{b}}$ & 0.03 & $1.07^{\mathrm{b}}$ & 0.03 & 1.71 & 0.08 & 1.15 & 0.06 \\
\hline FCR & $1.03^{\mathrm{a}}$ & 0.05 & $1.18^{\mathrm{b}}$ & 0.04 & $1.13^{\mathrm{b}}$ & 0.04 & 0.98 & 0.02 & 0.88 & 0.03 \\
\hline Feed intake $\left(\right.$ g.fish $\left.{ }^{-1} \cdot \mathrm{d}^{-1}\right)$ & 0.55 & 0 & 0.55 & 0 & 0.55 & 0 & 1.82 & 0.12 & 1.79 & 0.13 \\
\hline Condition factor & 1.52 & 0.04 & 1.6 & 0.04 & 1.59 & 0.11 & - & - & - & - \\
\hline
\end{tabular}

Values are means of triplicate tanks $(n=20$ per tank) \pm SD (experiment 1$)$ or $(n=10$ per tank $) \pm \operatorname{SD}$ (experiment 2$)$. Values without a common superscript letter differ significantly $(P<0.05)$ as calculated by one-way ANOVA and t test significant difference test

The absence of superscript indicates no significant difference between treatments (only applies for experiment 1; no statistical analysis was done in experiment 2)

In the present study, apparent nutrient and energy digestibility coefficients of trout and the pike perch diet were similar (Table 1). Therefore, the higher FCR in hybrid striped bass was not related to poor digestibility of the trout diet. Lemm et al. (1993) suggested that type and level of dietary essential fatty acids of trout diets do not reflect the requirements of hybrid striped bass which may also explain the present observed lower performance of hybrid striped bass fed the present trout diets. The better performance of hybrid striped bass fed with the pike perch diet was, however, somewhat unexpected because the pike perch diet showed the highest protein excess of all present diets (Table 1, 54\% compared to the reported requirement of around $40 \%$ (Brown et al. 1992; Nematipour et al. 1992; Webster et al. 2001)). In addition, the dietary lipid level of the pike perch diet (Table 1,18\%) was in excess of the species requirement which was estimated between 10 and 15\% (Gaylord and Gatlin 2000).

It is known that excess dietary protein and lipid levels can negatively influence the SGR and FCR in fish (Brown et al. 1992; Hatlen et al. 2007; Peres and Oliva-Teles 1999; Saravanan et al. 2012). Excess dietary lipid increases adiposity, which is thought to exert a negative feedback on feed intake via lipostatic regulation mechanisms (Johansen et al. 2002). This should have been reflected by low intake and low growth rates when pike perch diet is fed in unrestricted rations. No intake values and growth rates were found for hybrid striped bass of similar size. However, present SGR values (experiment 2, SGR of 1.7 and $1.15 \% \mathrm{~d}^{-1}$ in fish of 60.7 and $183 \mathrm{~g} \mathrm{IBW}$, respectively) are similar to values previously reported in hybrid striped bass of considerably smaller size; Juvenile hybrid striped bass (around 20-40 g IBW) fed diets formulated based on the known nutritional requirements showed SGR of 1.1-1.8 (Bowzer et al. 2016; Thompson et al. 2000) Similar sized juvenile hybrid striped bass fed a commercial salmonid diet showed SGR of 1.5\% (Hung et al. 1993). In addition, the moderate excess of dietary lipid in the pike perch diet (18\%, Table 2) did not seem to negatively influence FCR. In fact, present FCR values (Table 2, 0.88-0.98) compared favorably to FCR values previously reported in hybrid striped bass fed with diets of optimized dietary lipids levels of $12 \%$ (FCR of 1.1-1.5\% (Bowzer and Trushenski 2015; Thompson et al. 2000)). The absence of negative effects on FCR fed diet moderately in excess of dietary lipids requirements is in line with previous observations. Higher dietary lipid levels $>15 \%$ did not negatively influence feed efficiency in hybrid striped bass; however, the deposition of lipid in the liver and peritoneal cavity increased whereas the muscle yield decreased (Gaylord and Gatlin 2000). This was also observed in the present study. In this study, random individuals were sampled and showed excessive body fat depositions (unpubl. observation). The ADC values (Table 1) obtained in hybrid striped bass fed with the pike perch diet (and in those fed the two trout diets) are in the lower range of ADC values for feedstuff of animal origin previously reported for hybrid striped bass (Sullivan and Reigh 1995). However, considering the adequate FCR values, present ADC values may rather be a result of an inadequate fecal sampling method than related to low ingredient quality. In this study, settled feces were recovered twice per week. The recovery of settled feces may facilitate under estimation of digestibility due to disintegration/ 
separation of feces, or leaching of nutrients and/or marker from the fecal matter (Cho and Kaushik 1990). Disintegrated feces (as in the present study) are more susceptible to nutrient loss by leaching (Cho et al. 1985).

In conclusion, present results demonstrate that growth performance in hybrid striped bass can be improved when fishes are fed with commercial pike perch diets rather than using commercial trout diets as is the current practice. Key performance data in terms of growth (SGR) and growth by feed input (FCR) were better in hybrid striped bass fed with the pike perch diet compared to two trout diets. Acceptable growth rates were obtained when hybrid striped bass were fed with unrestricted rations of pike perch diet.

Acknowledgements This work was supported by 'The Central Innovation Programme for SMEs' (ZIM) from the Federal Ministry of Economic Affairs and Energy, BMWi (grand number Germany, ZF4010501SK5). The authors thank Mrs. Märkle (University of Applied Sciences Bremerhaven) for her support in the laboratory as well as staff from the 'Centre for Aquaculture Research' (ZAF) for conducting water quality analyses and helping with daily feeding and system management activities.

Open Access This article is distributed under the terms of the Creative Commons Attribution 4.0 International License (http:// creativecommons.org/licenses/by/4.0/), which permits unrestricted use, distribution, and reproduction in any medium, provided you give appropriate credit to the original author(s) and the source, provide a link to the Creative Commons license, and indicate if changes were made.

\section{References}

Bowzer J, Trushenski J (2015) Growth performance of hybrid striped bass, rainbow trout, and cobia utilizing Asian carp mealbased aquafeeds. N Am J Aquac 77:59-67. https://doi.org/10.1080/15222055.2014.960117

Bowzer J, Jackson C, Trushenski J (2016) Hybrid striped bass feeds based on fish oil, beef tallow, and eicosapentaenoic acid/docosahexaenoic acid supplements: Insight regarding fish oil sparing and demand for $n-3$ long-chain polyunsaturated fatty acids. J Anim Sci 94:978-988. https://doi.org/10.2527/jas.2015-9199

Brown ML, Nematipour GR, Gatlin DM (1992) Dietary Protein Requirement of Juvenile Sunshine Bass at Different Salinities Prog Fish Cul 54:148-156. doi:10.1577/1548-8640(1992)054<0148:dprojs >2.3.co;2

Brown ML, Jaramillo F, Gatlin DM (1993) Dietary phosphorus requirement of juvenile sunshine bass, Morone chrysops $\times$ M. saxatilis. Aquaculture 113:355-363

Bundesamt für Verbraucherschutz und Lebensmittelsicherheit (1980-09) Amtliche Sammlung von Untersuchungsverfahren nach § 64 LFGB, § 35 Vorläufiges Tabakgesetz, § 28b GenTG 1 (L), Verfahren zur Probenahme und Untersuchung von Lebensmitteln, Bestimmung des Gesamtfettgehaltes in Fleisch und Fleischerzeugnissen, ASU L0600-3

Bundesamt für Verbraucherschutz und Lebensmittelsicherheit (2004-07) Amtliche Sammlung von Untersuchungsverfahren nach $\S 64$ LFGB, § 35 Vorläufiges Tabakgesetz, § 28b GenTG 1 (L), Verfahren zur Probenahme und Untersuchung von Lebensmitteln, Bestimmung der säureunlöslichen Asche in Fleisch und Fleischerzeugnissen, ASU L4700-5

Bundesamt für Verbraucherschutz und Lebensmittelsicherheit (2004-07a) Amtliche Sammlung von Untersuchungsverfahren nach $\S 64$ LFGB, § 35 Vorläufiges Tabakgesetz, § 28b GenTG 1 (L), Verfahren zur Probenahme und Untersuchung von Lebensmitteln, Bestimmung der Rohprotein Gehaltes in Fleisch und Fleischerzeugnissen, ASU L1500-3

Bundesamt für Verbraucherschutz und Lebensmittelsicherheit (2004-07b) Amtliche Sammlung von Untersuchungsverfahren nach § 64 LFGB, § 35 Vorläufiges Tabakgesetz, § 28b GenTG 1 (L), Verfahren zur Probenahme und Untersuchung von Lebensmitteln, Bestimmung der Trockenmasse in Fleisch und Fleischerzeugnissen, ASU L0600-3

Bundesamt für Verbraucherschutz und Lebensmittelsicherheit (2004-074) Amtliche Sammlung von Untersuchungsverfahren nach § 64 LFGB, § 35 Vorläufiges Tabakgesetz, § 28b GenTG 1 (L), Verfahren zur Probenahme und Untersuchung von Lebensmitteln, Bestimmung der Asche in Fleisch und Fleischerzeugnissen, ASU L0600-4

Cho CY, Kaushik SJ (1990) Nutritional energetics in fish: energy and protein utilization in rainbow trout (Salmo gairdneri). In: Aspects of food production, consumption and energy values. Karger Publishers, pp 132-172

Cho CY, Cowey CB, Watanabe T (1985) Finfish nutrition in Asia: methodological approaches to research and development. International Development Research Centre, Manila

D'Abramo LR, Frinsko MO (2008) Hybrid Striped bass: pond production of food fish. SRAC publication, Stoneville

Deng DF, Wilson RP (2003) Dietary riboflavin requirement of juvenile sunshine bass (Morone chrysops $\times$ Morone saxatilis). Aquaculture 218:695-701

FAO (2016) Cultured aquatic species information programme. Morone hybrid. FAO Fisheries and Aquaculture Department, Rome

Gaylord TG, Gatlin DM (2000) Dietary lipid level but not 1-carnitine affects growth performance of hybrid striped bass (Morone chrysops $\times$ M. saxatilis). Aquaculture 190:237-246

Gaylord TG, Rawles SD, Davis KB (2005) Dietary tryptophan requirement of hybrid striped bass (Morone chrysops $\times$ M. saxatilis). Aquac Nutr 11:367-374

Griffin ME, Wilson KA, Brown PB (1994) Dietary arginine requirement of juvenile hybrid striped bass J Nutr 124:888-893

Hatlen B, Helland SJ, Grisdale-Helland B (2007) Energy and nitrogen partitioning in $250 \mathrm{~g}$ Atlantic cod (Gadus morhua L.) given graded levels of feed with different protein and lipid content. Aquaculture 270:167-177

Hillestad M, Åsgård T, Berge GM (1999) Determination of digestibility of commercial salmon feeds. Aquaculture 179:81-94 
Hung SSO, Conte FS, Hallen EF (1993) Effects of feeding rates on growth, body composition and nutrient metabolism in striped bass (Morone saxatilis) fingerlings. Aquaculture 112:349-361

Jaramillo F, Gatlin DM (2004) Comparison of purified and practical diets supplemented with or without $\beta$-glucan and selenium on resistance of hybrid striped bass Morone chrysops $+\times$ M. saxatilis $\widehat{\jmath}$ to Streptococcus iniae infection. J World Aquac Soc 35:245-252 https://doi.org/10.1111/j.1749-7345.2004.tb01081.x

Johansen SJS, Ekli M, Jobling M (2002) Is there lipostatic regulation of feed intake in Atlantic salmon Salmo salar L.? Aquacult Res 33:515-524. https://doi.org/10.1046/j.1365-2109.2002.00736.x

Keembiyehetty CN, Gatlin DM (1997) Dietary threonine requirement of juvenile hybrid striped bass (Morone chrysops $\times$ M saxatilis). Aquac Nutr 3:217-221

Keembiyehetty CN, Wilson RP (1998) Effect of water temperature on growth and nutrient utilization of sunshine bass (Morone chrysops $\bigcirc \times$ Morone saxatilis $\widehat{\bigcirc})$ fed diets containing different energy/protein ratios. Aquaculture 166:151-162

Kocabas AM, Gatlin DM (1999) Dietary vitamin E requirement of hybrid striped bass (Morone chrysops female $\times$ M. saxatilis male). Aquac Nutr 5:3-8

Kohler CC (2004) A white paper on the status and needs of hybrid bass aquaculture in the north central region. NCRAC White Papers, Paper, p 2

Lemm CA, Herman RL, Lemarie DP, Arzapalo A (1993) Effects of diet and environmental salinity on the growth, mortality, and tissue structure of juvenile striped bass. J Aquat Anim Health 5:294-305

Liu FG, Liao IC (1999) Effect of feeding regimen on the food consumption, growth, and body composition in hybrid striped bass Morone saxatilis $\times$ M. chrysops. Fish Sci 65:513-519. https://doi.org/10.2331/fishsci.65.513

Lougheed M, Nelson B (2001) Hybrid striped bass production, markets and marketing. Michigan State University, East Lansing

Maynard LA, Loosli JK, Hintz HF, Warner RG (1979) Animal Nutrition. 7th edn. New York

Morris JE, Kohler CC, Mischke CC (1999) Pond culture of hybrid striped bass in the North Central Region

Nematipour GR, Brown ML, Gatlin DM (1992) Effects of dietary energy: protein ratio on growth characteristics and body composition of hybrid striped bass, Morone chrysops x M. saxatilis. Aquaculture 107:359-368

Peres H, Oliva-Teles A (1999) Effect of dietary lipid level on growth performance and feed utilization by European sea bass juveniles (Dicentrarchus labrax). Aquaculture 179:325-334

Saravanan S, Geurden I, Figueiredo-Silva AC, Kaushik SJ, Haidar MN, Verreth JA, Schrama JW (2012) Control of voluntary feed intake in fish: a role for dietary oxygen demand in Nile tilapia (Oreochromis niloticus) fed diets with different macronutrient profiles. Br J Nutr 108:1519-1529. https://doi.org/10.1017/s0007114511006842

Sealey WM, Gatlin DM (1999) Dietary vitamin C requirement of hybrid striped bass Morone chrysops $\times$ M. saxatilis. J World Aquac Soc 30:297-301

Sullivan JA, Reigh RC (1995) Apparent digestibility of selected feedstuffs in diets for hybrid striped bass (Morone saxatilis $\times$ Morone chrysops). Aquaculture 138:313-322

Thompson KR, Webster CD, Morgan AM, Grisby EJ (2000) Effects of different feeding frequencies on growth, body composition, and fillet composition of juvenile sunshine bass, Morone chrysops $\times$ M. saxatilis grown indoors. J Appl Aquacult 10:55-65. https://doi.org/10.1300/J028v10n02_05

Tucker Jr JW (2012) Marine fish culture. Springer Science \& Business Media

Webster CD, Tiu LG, Tidwell JH, Van Wyk P, Howerton RD (1995) Effects of dietary protein and lipid levels on growth and body composition of sunshine bass (Morone chrysops $\times$ M. saxatilis) reared in cages. Aquaculture 131:291-301

Webster CD, Thompson KR, Morgan AM, Grisby EJ, Dasgupta S (2001) Feeding frequency affects growth, not fillet composition, of juvenile sunshine bass Morone chrysops $\times$ M. saxatilis grown in cages. J World Aquac Soc 32:79-88. https://doi.org/10. 1111/j.1749-7345.2001.tb00925.x

\section{Publisher's Note}

Springer Nature remains neutral with regard to jurisdictional claims in published maps and institutional affiliations. 